\title{
Accelerating Learning with Distance Education and Open Courseware
}

George K. Thiruvathukal

Loyola University Chicago, gkt@cs.luc.edu

Follow this and additional works at: https://ecommons.luc.edu/cs_facpubs

Part of the Computer Sciences Commons

\section{Recommended Citation}

G. K. Thiruvathukal, "Accelerating Learning with Distance Education and Open Courseware," in Computing in Science \& Engineering, vol. 14, no. 4, pp. 4-5, July-Aug. 2012, doi: 10.1109/MCSE.2012.70.

This Article is brought to you for free and open access by the Faculty Publications and Other Works by Department at Loyola eCommons. It has been accepted for inclusion in Computer Science: Faculty Publications and Other Works by an authorized administrator of Loyola eCommons. For more information, please contact ecommons@luc.edu.

\section{(c) (1) 9(}

This work is licensed under a Creative Commons Attribution-Noncommercial-No Derivative Works 3.0 License. 


\title{
F R O M \\ THE E DITOR S
}

\section{ACCELERATING LEARNING WITH DISTANCE EDUCATION AND OPEN COURSEWARE}

\author{
By George K. Thiruvathukal, Associate Editor in Chief
}

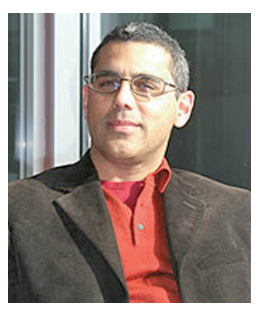

HE TIME FOR THE DISRUPTIVE TECHNOLOGY KNOWN AS ONLINE EDUCATION OR DISTANCE LEARNING CAME RECENTLY_DEPENDING ON WHEN YOU STARTED COUNTING-OR, MORE PRECISELY, SOMETIME IN THE MID-1990S

WITH THE ADVENT OF THE WEB. SO WHEN HARVARD AND MIT ANNOUNCED

their partnership to form edX-a name reminiscent of the ed text editor-it sent a shockwave throughout the academic community about what this means for the future of education. Despite not being a new idea (MIT is one of the pioneers in open courseware and online delivery, and the Khan Academy received a good amount of press before this happened) and really being in some ways a subgenre of a broader trend toward more open access of content, the MIT + Harvard announcement left many scratching their heads about what this will mean, especially if only a subset of experts in elite places deliver largely the same content as offered onsite at most universities.

\section{A New Phase}

As I see it, this shift in education isn't an enormous source of concern, but it will result in change-just as the Internet has changed newspapers, magazines, and (now) publications similar to ours. In general, the Web is doing what it promised to do in the first place: make academic and scientific content available to as many as possible (worldwide) and to diffuse knowledge and opportunity. With the growing number of mobile devices, you could say that the Internet and Web are entering a new phase, one that's characterized by rapid acceleration-a theme that plays out in a recent album, Accelerando, by the Vijay Iyer Trio. For my 25th birthday (in base 20), I received the $\mathrm{CD}$ version of this album. One of the distinct advantages of "getting the CD" is that you can easily find the liner notes, where delightful surprises often await. In the liner notes, Vijay writes in lowercase,

if music is action, then it is best heard in context. today's context sounds like acceleration: rising inequality, populist revolution, economic crisis, climate change, moore's law, global connectivity. as the flow of information gets faster, denser, and more intricately networked, our attention shifts to larger forms, the slower tempos that gracefully evolve like the spiral forms of a burricane.

These are the brainy words of the musician, whose educational background reminds me of the typical reader of this publication. His undergraduate studies were in mathematics and physics, after which he pursued an interdisciplinary $\mathrm{PhD}$ at Berkeley in technology and the arts with a focus on music and human cognition. His liner notes clearly reflect an interconnected nature of the world he lives in - a world he embraces, despite its disruptive nature. In his list, we could have easily added words about education. Online education has a significant role to play in the study of networked things and might be necessary to break the unidisciplinary silos that predominate in so many universities. As Vijay put it so eloquently, our attention can shift to larger forms as a result of understanding the growing number of connections and complexity thereof.

\section{Embracing and Shifting Focus}

I cannot speak for all disciplines, but I see the move to online education not as disruptive but potentially one where the relationship is inverted in a way that augments the instructional time for students without creating more work for the instructor. The computing discipline, for example, is much like music. When I last checked, you still need to learn to play the instrument, and playing it well takes a lifetime to master beyond your education. For CiSE-related disciplines, I see online education as accelerating the trend 


\section{Cise Welcomes NeW BOARD MEMBERS}

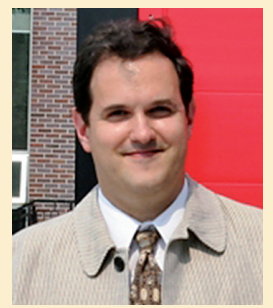

abriel A. Wainer is a professor in the Department of Systems and Computer Engineering and is the head of the Advanced Real-Time Simulation Lab at Carleton University in Ottawa, Canada. His research interests are focused in the areas of discrete event modeling and simulation, parallel and distributed simulation, and real-time systems. Wainer has a $\mathrm{PhD}$ in computer engineering from the Université d'Aix-Marseille III, France. He's the special issues editor of SIMULATION and a member of the editorial boards of Wireless Networks, Journal of Defense Modeling and Simulation, and
International Journal of Simulation and Process Modeling. Contact him at Gabriel.Wainer@sce.carleton.ca; further information can be found at www.sce.carleton.ca/faculty/wainer.

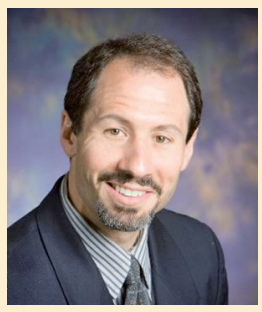

$\triangle$ ndrew Singer is a professor in and Computer Engineering and the Coordinated Science Laboratory at the University of Illinois at UrbanaChampaign. His research interests include signal processing and communication systems. Singer has a PhD in electrical engineering and computer science from the Massachusetts Institute of Technology. He has served as an associate editor for the IEEE Transactions on Signal Processing and is an IEEE Fellow. Contact him at acsinger@ illinois.edu. toward communities of practice (a group of folks who share a craft or a profession), which also requires a more collaborative methodology for learning (ideas that are already prevalent in the free or open source software community).

In this "disruptive" worldview, a professor would put most course materials and lectures online and use classroom-or better yet, lab-time to support active learning and student engagement. The model would probably take on the nature of a jazz ensemble, where the professor/instructor presents a theme and music is made as a group. Students (being the group members) would elaborate on the theme by working on it during class time, presenting their work in class, and even improvising upon it, which as we all know is where the real learning (and fun) occurs. Less time would be spent on lecturing and more time would be spent helping students develop their craft.

In applied disciplines such as computer science, it's abundantly clear that this craft takes time to learn, and students benefit greatly from spending more time in class working on homework and projects. This year, I decided to shift some of my personal energy from advanced graduate-level courses to undergraduate teaching, because I wanted to explore how distance learning technologies could augment the onsite experience for introductory computer science students. I partnered with my colleague Andrew Harrington, who was teaching the same course, to develop a collection of what we hoped were pedagogically sound materials for learning the discipline-with the hope that students could learn much on their own by studying and running all of the examples whenever they like (in or out of class). We made significant progress toward developing an online book and robust instructional materials, which can be viewed at http://introcs.courses.thiruvathukal.com. We're not done yet, but we hope that our efforts will have an impact beyond Loyola University. Because this work is open source, we welcome contributions and input from others, so please don't hesitate to get in touch with us. 'm hoping to write a longer article about publishing

tools in a future CiSE issue, but I'll say for now that we used the Sphinx documentation tools (http://sphinx. pocoo.org) from the Python community to develop versions of our book and notes for whatever device students want to use: desktop browsers, mobile Web browsers, mobile e-reading clients, and good old PDF (for those who still want beautifully printed versions). Students seemed genuinely pleased that their professors would actually give them a book for the course (a savings of over $\$ 125$, given the current CS1 textbook space; CS1 is the Association for Computing Machinery's terminology for the first computer science or programming course). They also seemed delighted that more time could be spent in class on their work as opposed to endless lecturing, only to go home and not know where to begin on the crafting part (which can cause trouble for newbies in CS, as my colleague likes to put it). It's much better to be in class when you're working on programming assignments (especially in the first few weeks), where you can get help from a human.

So, if this approach is any indication of what comes next for education, it might go something like this: teach online, learn and develop the craft onsite. The future will hybridize an online and in-class educational approach, and further disruption is ahead. We already know from years of teaching computing that you still need to spend time outside of class to learn it well, but the addition of online and free academic materials to the mix should (pardon the reference) help students accelerate their learning of a complex discipline. publications are also available for free at bttp://ComputingNow. computer.org. 